\title{
THE HEPATOPROTECTIVE ROLE OF THE ZAKARPATTIA HERBAL PREPARATIONS IN EXPERIMENTAL ATHEROSCLEROSIS AND DIABETES MELLITUS TYPE 2
}

\author{
Biloshytska A.V.
}

\section{ГЕПАТОПРОТЕКТОРНА РОЛЬ РОСЛИННИХ ПРЕПАРАТІВ ЗАКАРПАТТЯ ПРИ ЕКСПЕРИМЕНТАЛЬНИХ АТЕРОСКЛЕРОЗ ТА ЦУКРОВОМУ ДІАБЕТІ 2-ГО ТИПУ}

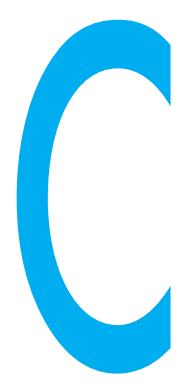

БІЛОшицЬКА А.В.

Вінницький національний медичний університет ім. М.І. Пирогова

Удк 616.36-007: 616.379-00864: 616.13-004.6-084

Ключові слова: атеросклероз, цукровий діабет 2-го типу, печінка, фітопрофілактика.

учасна політична ситуація в Україні негативно впливає на стан здоров'я українців, призводячи до різкого зростання кількості пацієнтів з атеросклерозом та цукровим діабетом 2-го типу, які вражають не тільки органи серцевосудинної системи, але й травної, зокрема печінку. Вітчизняні лікарі вже б'ють на сполох: формування у наших співгромадян гострого і хронічного стресу $\epsilon$ підґрунтям для поширення і загострення проблеми виникнення атеросклерозу та його маніфестантних форм [1].

Незважаючи на те, що крилатим словам $\mathrm{H}$. Анічкова «без холестерину немає атеросклерозу» вже більше 100 років, значення його відкриття, на думку Американської

ГЕПАТОПРОТЕКТОРНАЯ РОЛЬ РАСТИТЕЛЬНЫХ ПРЕПАРАТОВ ЗАКАРПАТЬЯ ПРИ ЭКСПЕРИМЕНТАЛЬНЫХ АТЕРОСКЛЕРОЗЕ И САХАРНОМ ДИАБЕТЕ

Билошицкая А.В.

Винницкий национальный медицинский университетим. Н.И. Пирогова

Актуальность. Ныне атеросклероз и сахарный диабет 2-го типа - наиболее социально-значимые заболевания. Ситуация усугубляется хроническим стрессом, который испытывает украинский народ. Среди органов-мишеней, страдающих в первую очередь, - печень.

Цель. Изучить структурную перестройку печени при экспериментальных атеросклерозе и сахарном диабете, а также при профилактике растительными препаратами.

Материалы и методы. Исследование проведено на 50 крысахсамцах. Использовалась классическая модель атеросклероза Аничкова и дексаметазоновая модель сахарного диабета. В качестве профилактического средства использовался отвар из лекарственных растений Закарпатья в авторской пропорции.

Результаты. Экспериментальное моделирование атеросклероза и сахарного диабета показало, что в печени развиваются дистрофические изменения. Эти изменения наиболее выражены в группе с одновременным моделированием патологий.

Профилактическое введение фитопрепарата из традиционных лекарственных растений Закарпатья имело выраженный гепатопротекторный эффект.

Выводы. Экспериментальный атеросклероз и сахарный диабет приводят к дистрофическим изменения в паренхиме и строме печени. Профилактическое введение отвара из лекарственных растений Закарпатья имеет гепатопротекторное влияние, что подтверждается морфологически.

Ключевые слова: атеросклероз, сахарный диабет 2-го типа, печень, фитопрофилактика. академії наук, входить до десятка найважливіших у галузі медицини. Внесок Н. Анічкова у науку про роль холестеролу в етіопатогенезі атеросклерозу порівнюється з відкриттям Р. Кохом палички туберкульозу. Відомий постулат $€$ актуальним і сьогодні, хоч існують десятки теорій виникнення та розвитку атеросклерозу. Але ніхто не заперечує, і це підтверджують дані американських та європейських досліджень, що саме холестерол відіграє провідну роль в атерогенезі. Саме Н. Анічков вважав, що атерогенез має системний характер, і нині це беззаперечно [2].

Останнім часом все частіше поєднують атеросклероз та цукровий діабет 2-го типу. Вважається, що цукровий діабет, тяжке прогресуюче ендокринне захворювання, етіопатогенетично пов'язаний з атеросклерозом [3].

Деякі дослідники взагалі вважають атеросклероз та цукровий діабет симптомами метаболічного синдрому [4], що дає можливість думати про їхню спільну причину та взаємозв'язок [5].

У США підрахували, що високотехнологічні методи лікування атеросклерозу загалом не вплинули на загальну смертність, їхній вклад становить близько 5\% [2]. Незважаючи на виникнення все нових класів медичних препаратів лікування пацієнтів з цукровим діабетом 2-го типу залишається важким і не завжди вдалим [5].

Невпинне поширення захворювань серцево-судинної системи в Україні та світі створює умови, в яких виникає необхідність пошуку та впровадження нових методів лікування та профілактики цих захворювань [6]. Вод-

๔ Б Білошицька А.В. СТАТТЯ, 2016. 
THE HEPATOPROTECTIVE ROLE OF THE ZAKARPATTIA HERBAL PREPARATIONS IN EXPERIMENTAL ATHEROSCLEROSIS AND DIABETES MELLITUS TYPE 2 Biloshytska A.V.

M.I. Pyrogov National Medical University, Vinnytsia

Background. Today atherosclerosis and type 2 diabetes mellitus are the most socially significant diseases. The situation is aggravated by chronic stress experienced by the Ukrainian people. There is a liver among target organs which are affected primarily.

Objective. We studied the structural reconstruction of the liver tissue during the experimental atherosclerosis and diabetes mellitus and at its prophylaxis with herbal preparations.

Materials and methods. The study was performed on 50 male rats. We used the classical model of atherosclerosis by N. Anichkov and dexamethasone suppres- sion model of diabetes mellitus. We used a decoction of the Zakarpattia medicinal plants (by our recipe) as a prophylactic agent.

Results. Experimental model of atherosclerosis and diabetes mellitus showed that degenerative changes had been developed in the liver. These changes are the most pronounced in the group with the concurrent simulation of pathologies. Prophylactic administration of traditional medicinal plants of Zakarpattia had pronounced hepatoprotective effect.

Conclusions. Experimental atherosclerosis and diabetes mellitus lead to the degenerative changes in the liver parenchyma and stroma. Prophylactic administration of decoction of medicinal plants of Zakarpattia has hepatoprotective effect confirmed by the morphological studies.

Keywords: atherosclerosis, type 2 diabetes mellitus, liver, phytoprophylaxis. ночас відзначено, що в останне десятиріччя не з'явилося жодної синтезованої речовини, а найменш шкідливими і терапевтично ефективними $є$ препарати природного походження, які не такі токсичні і мають більш м'яку дію, що зумовлено спорідненістю метаболізму рослинної та тваринної клітини. Рослини, як провідний компонент харчування, включаються у метаболізм, позитивно впливають на усі органи та їхній функціональний стан, сприяють максимальній біодоступності та комплексній дії за рахунок широкого спектра біологічно-активних речовин [7].

Основні ланки патогенезу атеросклерозу та цукрового діабету 2-го типу мають дуже тісні зв'язки з функціональним станом шлунково-кишкового тракту, особливо печінки. Оксидативний стрес, ендотеліальна дисфункція, зміни ліпідного цитокінового спектра крови призводять до порушень функції печінки, а відповідний дисбаланс у регуляції вуглеводного обміну сприяє тому, що хронічна гіперглікемія, наявна при цукровому діабеті 2-го типу, запускає каскад патологічних реакцій [4].

Існує чимало робіт, присвячених окремому вивченню структури печінки при експериментальному атеросклерозі та цукровому діабеті, але ці захворювання розглядались як окремі нозології [8].

Метою нашої роботи стало вивчення структурної перебудови печінки при одночасному моделюванні атеросклерозу і цукрового діабету 2-го типу та гепатопротекторної дії традиційних лікарських рослин Закарпаття на рівні доказової медицини.

Матеріали та методи. Дослідження проводилось на 50 білих лабораторних щурах.
Усі піддослідні тварини були розподілені на 5 груп (по 10 тварин): 1 група - інтактні, 2 - щури, яким моделювався цукровий діабет (переддіабет), 3 - щури, яким моделювався експериментальний атеросклероз за класичною методикою Анічкова, 4 одночасне моделювання атеросклерозу та цукрового діабету, 5 - профілактика цукрового діабету та експериментального атеросклерозу фітопрепаратом із традиційних лікарських рослин Закарпаття. Протягом 30 днів щурам 3, 4 та 5 груп внутрішньошлунково за допомогою зонду 3 оливою вводився холестерол у дозі 0,5 г/кг і додатково метил-2-тіоурацилу для пригнічення функції щитовидної залози [9]. Протягом 14 днів щурам 2, 4 та 5 груп внутрішньошкірно вводився дексаметазон для відтворення порушення толерантності до глюкози. До-

\section{Показники масоморфометричних вимірювань органів щурів}

\begin{tabular}{|l|c|c|c|}
\hline Показник & $\begin{array}{c}\text { Маса } \\
\text { початкова (г) }\end{array}$ & $\begin{array}{c}\text { Маса } \\
\text { наприкінці } \\
\text { досліду (г) }\end{array}$ & Печінка (г) \\
\hline $1(n=10)$ & $232,5 \pm 68,00$ & $232,75 \pm 25,10$ & $7,52 \pm 1,56$ \\
\hline $2(n=10)$ & $224,38 \pm 18,74$ & $181,63 \pm 21,24^{\star}$ & $6,58 \pm 0,78^{\star}$ \\
\hline $3(n=10)$ & $230,63 \pm 23,16$ & $195,5 \pm 33,25^{\star}$ & $6,9 \pm 1,16^{\star}$ \\
\hline $4(n=10)$ & $227,25 \pm 14,87$ & $191,38 \pm 18,18^{\star}$ & $7,28 \pm 0,90^{\star}$ \\
\hline $5(n=10)$ & $213,58 \pm 12,47$ & $201,66 \pm 21,7^{\star} \#$ & $7,76 \pm 0,88^{\star} \#$ \\
\hline
\end{tabular}

\section{Примітка:}

* - різниця достовірна порівняно з групою інтактних тварин ( $p \leq 0,05)$, \# - різниця достовірна порівняно з групою тварин з експериментальною патологією $(p \leq 0,05)$.
Рисунок 1 Печінка інтактної тварини. Забарвлення гематоксилін-еозином. Зб.: ок.10, об.8

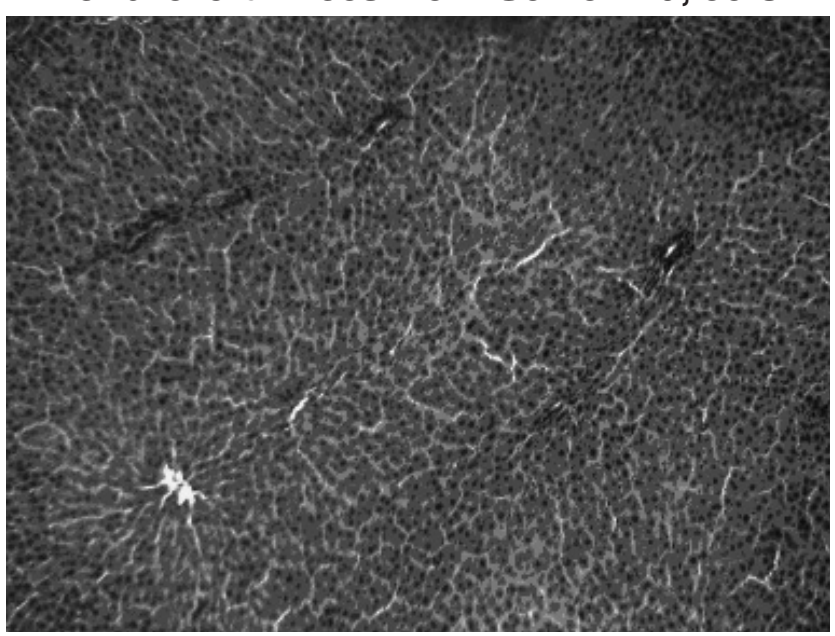


ведено, що зниження утилізації глюкози адипоцитами після ін'єкції дексаметазону є наслідком його прямого впливу на експресію транспортерів глюкози GLUT1 та GLUT4, що призводить до розвитку інсулінорезистентності. Дексаметазоновий діабет дозволяє відтворити головні патогенетичні механізми цукрового діабету 2-го типу (порушення секреції інсуліну та розвитку інсулінорезистентності), що спостерігаються у хворих. Введення дексаметазону у дозі 0,125 мг/кг маси тіла протягом 14 днів внутрішньошкірно щурам віком 4 місяці дозволяє створити так званий переддіабет [10]. Тваринам 5 групи на тлі цукрового діабету та атеросклерозу вводився фітопрепарат із традиційних рослин Закарпаття (листя чорниці, стулки квасолі, насіння льону, січка соломи вівса, трава галеги, корінь і листя кульбаби, листя кропиви дводомної, корінь валеріани, листя мучниці, листя волоського горіха, коріння, листя та квіти бузини чорної, липовий цвіт, звіробій, спориш, корінь оману, січка соломи вівса тощо) в авторській пропорції (2 мл у розведенні 1:10 внутрішньошлунково).

Утримання тварин та маніпуляції проводилися відповідно до положень «Європейської конвенції про захист хребетних тварин, які використовуються для експериментальних та інших наукових цілей» (Страсбург, 1985), «Загальних етичних принципів експериментів на тваринах», ухвалених I Національним конгресом з біоетики (Київ, 2001), а також комітету з біоетики Вінницького національного медичного університету імені М.І. Пирогова (протокол № 11 від 07.06.2012 р.). Тварин виводили з експерименту шляхом декапітації під легким ефірним наркозом. Масометричне дослідження показало, що протягом експерименту змінювалася маса піддослідних тварин. Так, за 14 днів експерименту маса тварин інтактної групи майже не змінилася. Водночас тварини з експериментальним цукровим діабетом втратили майже $20 \%$ від початкової маси тіла, тварини з експериментальним атеросклерозом - 15,2\% маси, тварини 3 одночасним моделюванням обох патологій - майже $16 \%$ маси тіла, а при експериментальному цукровому діабеті, атеросклерозі та лікувальному введенні фітопрепарату маса виявилася меншою лише на 5\% від початкової. Маса печінки тварин з експериментальним цукровим діабетом була на 13\% меншою від маси органа тварин інтактної групи, маса печінки тварин з експериментальним атеросклерозом була меншою на 8\%. Одночасне моделювання патологій призводило до зменшення органа на 3\%, а профілактичне введення фітопрепарату - до збільшення маси органа на 3\% порівняно з інтактною групою (табл.).

Для морфологічних досліджень були використані загальноприйняті гістологічні методи. Гістологічні препарати забарвлювали гематоксиліном та еозином, вивчали із застосуванням системи аналізування гістологічних зрізів. На монітор комп'ютера виводили зображення з мікроскопа за допомогою відеокамери і спеціальної програми.

Гістологічне дослідження печінки показало, що при світловій мікроскопії у печінці інтактних щурів ідентифікували строму і паренхіму. Строма представлена тонкою сполучнотканинною капсулою та прошарками сполучної тканини $з$ кровоносними та лімфатичними судинами і жовчними протоками. Паренхіма печінки представлена епітеліальними клітинами - гепатоцитами, які компонуються у класичні печінкові часточки. Часточки печінки цієї групи щурів ототожнюються досить
Печінка тварини з експериментальним атеросклерозом. Забарвлення

гематоксилін-еозином. Зб.: ок.10, об.8

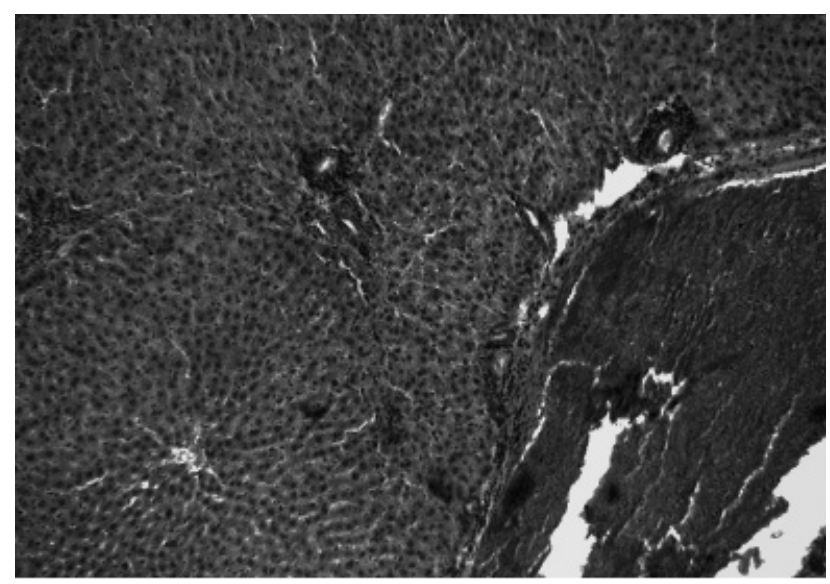

Рисунок 3

\section{Печінка тварини з експериментальним} цукровим діабетом.

Зб.: ок. 10, об.8

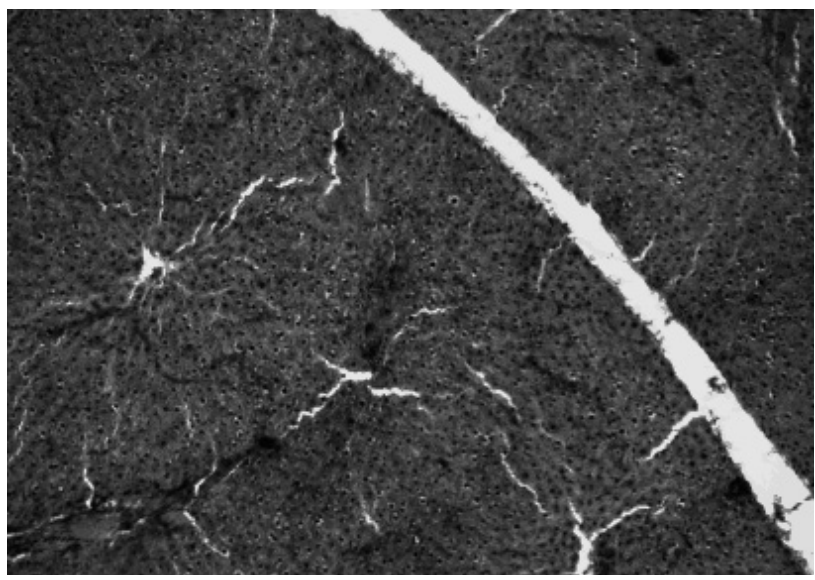

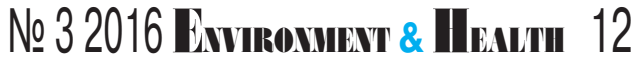


важко, оскільки вони чітко не відділені одна від одної сполучнотканинними прошарками, що характерно для цього виду тварин. Форма класичних печінкових часточок нагадує п'яти- або шестикутники з закругленими кутами, в яких можна спостерігати портальну зону, або тракт, що складається 3 поперечно зрізаних гілок міжчасточкової печінкової артерії, ворітної вени, жовчного протоку та лімфатичних судин разом з нервами та пухкою сполучною тканиною, в якій вони всі містяться. У центрі класичних печінкових часточок проходить центральна вена з округлим отвором, часом заповнена форменними елементами крови. Від центральної вени у радіальному напрямку розташовуються неправильними розгалуженими рядами гепатоцити. Цитоплазма гепатоцитів має гомогенний характер. Ядра гепатоцитів, як правило, мають округлу форму, по 1-2 ядерця, які можна добре розрізнити. Найчастіше у класичних часточках зустрічаються гепатоцити 3 одним ядром, але поблизу портальних трактів спостерігаються і двоядерні клітини. У печінкових пластинках гепатоцити розташовуються двома рядами, між якими містяться синусоїди у вигляді щілинних просторів. Стінку синусоїдів створюють зірчасті ендотеліоцити та макрофагоцити. Ядра ендотеліоцитів мають вигляд коротких тонких паличок, а ядра макрофагів - трикутну, призматичну або витягнуту овальну форму. Зрідка зустрічаються жиронакопичувальні клітини (рис. 1)

Під час мікроскопічного дослідження препаратів печінки щурів з експериментальним атеросклерозом виявлено, що гепатоцити мають світлу цитоплазму з оптично порожніми вакуолями та базофільною зернистістю. У печінці щурів з експериментальним атеросклерозом ми спостерігали збільшення кількості сполучної тканини, виявляли вогнища крововиливів, часточки печінки розрізняли за наявними міжчасточковими сполучно-тканинними прошарками, в яких визначали макрофаги, лімфоцити, клітини фібробластного ряду, пучки колагенових волокон. Помітно було порушення двохшарової структури печінкових пластинок, розширення простору синусоїдних капілярів (рис. 2).

При експериментальному цукровому діабеті у тканині печінки відзначалася збережена часточкова будова. У центролобулярній зоні спостерігались ділянки з порушенням радіального розташування печінкових балок, синусоїдні капіляри були значно розширені. Гепатоцити у таких ділянках часто були без'ядерними, оптично вакулолізованими. У гепатоцитах зі збереженими ядрами спостерігався їх набряк, гіперхромність. Частина клітин мала набряклу цитоплазму з великою кількістю оптично порожніх вакуоль. У центролобулярній зоні також зустрічались поодинокі вогнища некрозу гепатоцитів 3 великою кількістю лімфоцитів. У розширених просвітах синусоїдних капілярів та центральних вен спостерігались тромби. Ендотеліоцити синусоїдних капілярів були неоднорідно забарвленими. Відзначалася велика кількість макрофагів. У перипортальній зоні також спостерігалася дистрофія та некроз гепатоцитів. Дистрофія мала характер жирового переродження гепатоцитів (рис. 3).

При одночасному моделюванні атеросклерозу та цукрового діабету відзначалася тотальна втрата часточкової будови печінки. Гепатоцити були розташовані хаотично, не формували печінкових балок. Часто виявлялися без'ядерні клітини 3 великою кількістю оптично порожніх вакуоль. Ділянки дистрофії та некрозу
Печінка тварини з одночасним моделюванням патологій. Забарвлення гематоксилін-еозином. Зб.: ок.10, об.8

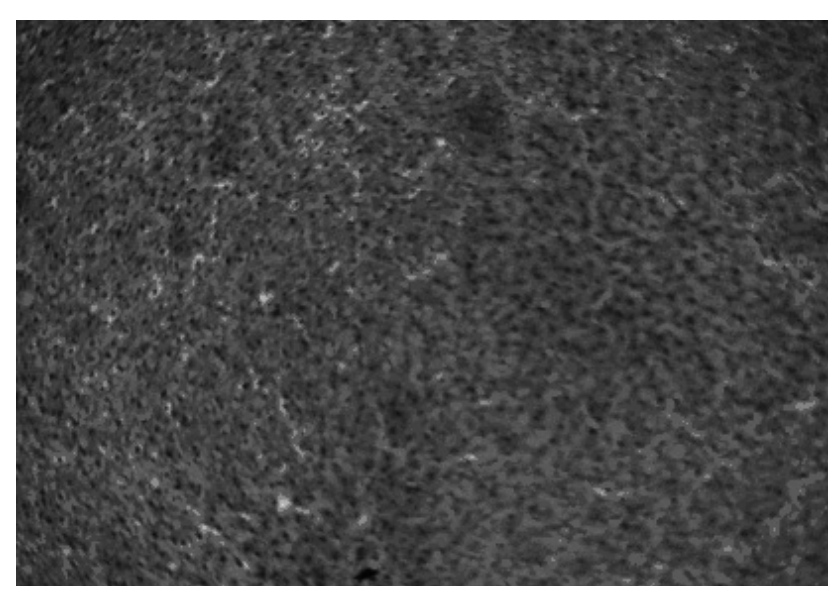

Рисунок 5

Печінка тварини з лікувальним введенням відвару традиційних лікарських рослин Закарпаття на тлі одночасного моделювання патологій. Забарвлення гематоксилін-еозином. Зб.: ок. 10, об.8

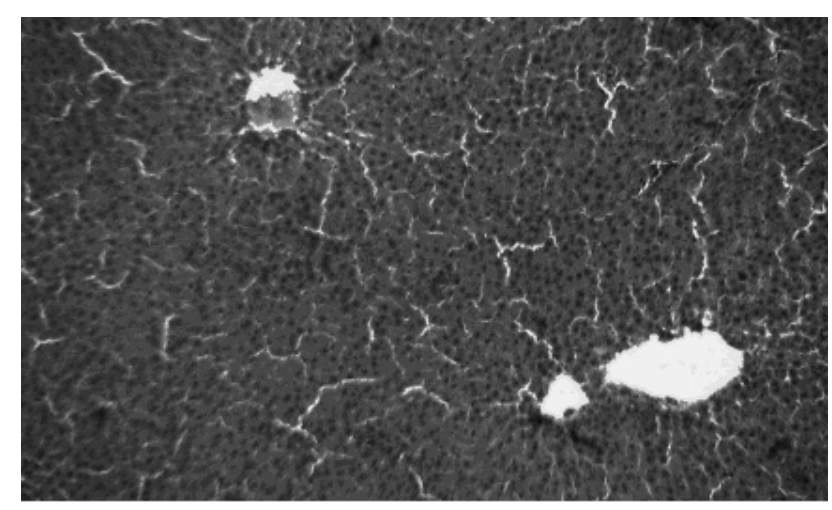


рослин Закарпаття має гепатопротекторний вплив.

Вважається перспективним подальше вивчення органопротекторної дії рослинних препаратів Закарпаття при експериментальному атеросклерозі та цукровому діабеті 2-го типу на рівні доказової медицини.

ЛІТЕРАТУРА

1. Європейський самміт погоджується, що єдиною відповіддю на серцево-судинні захворювання мають бути зміни у способі життя // Ліки України. - 2010. - № 10. С. 39-40.

2. Рудык Ю.С. Контроль липидов в клинической практике: возможно ли улучшение? // Ліки України. - 2014. - № 10. - С. 54-56.

3. Соломенчук Т.М. Сучасні принципи кардіоваскулярної профілактики у хворих на цукровий діабет 2-го типу / Т.М. Соломенчук, І.В. Білавка O.В. Восух // Ліки України. 2010. - № 10. - C. 48-53.

4. Журавльова Л.В.

Цукровий діабет 2-го типу та хронічний панкреатит: одна залоза - дві проблеми / Л.В. Журавльова,

Ю.О. Шеховцова // Ліки України. - 2014. - № 9. C. 11-14.

5. Марусин О.В.

Взаємозв'язок між вуглеводним та ліпідним обміном у пацієнтів з цукровим діабетом 2-го типу // Галиційський лікарський вісник. - 2012. T. 19 (2). - C. 60-62.

6. Базилевич А.Я.

Необхідність зниження рівня холестерину у крови як запорука ефективного лікування серцево-судинних захворювань // А.Я. Базилевич,

О.М. Барна // Ліки України. 2014. - № 9. - C. 45-50.

7. Растительные препараты в лечении соматоморфных расстройств и вегетативной дисфункции / В.Ю. Приходько, Е.А. Кононенко, Д.Ю. Морева и др. // Ліки України. - 2014. - № 9. - С. 15-21.

8. Согуйко Ю.Р.

Морфологічні особливості печінки щура у нормі та при експериментальному цукровому діабеті на ранніх етапах, перебіг // Укр. морфологічний альманах. - 2014. - Т. 10, № 2. - C. 137-140.i
9. Доклінічні дослідження лікарських засобів : метод. рек. / О.В. Стефанов (ред.). Київ : Авіценна, 2001.

-528 с.

10. Пат. № (19) KZ

(13)AU(11) MПК A61K 31/573

Способ воспроизведения сахарного диабета 2 типа у молодых крыс / А.М. Месова, Б.А. Исаханова, М.Ж. Еспенбетова, Б.А. Жетписбаев. № 22018; опубл. 15.02.2009 ; Бюл. № 12.

REFERENCES

1. Yevropeyskyi samit

pohodzhuietsia, shcho yedynoiu vidpoviddiu na sertsevo-sudynni zakhvoriuvannia maiut buty zminy u sposobi zhyttia [The European Summit Agrees that the Changes in the Way of Life Must be the Only Answer to the Cardio-Vascular Diseases].

LikyUkrainy. 2010; 10 : 39-40 (in Ukrainian).

2. Rudyk Yu.S. Liky Ukrainy.

2014; 10 : 54-56 (in Russian).

3. Solomenchuk T.M.,

Bilavka I.V., Vosukh O.V.

Liky Ukrainy. 2010; 10 : 48-53

(in Ukrainian).

4. Zhuravliova L.V.,

Shekhovtsova Yu.O. Liky

Ukrainy. 2014; 9 : 11-14 (in

Ukrainian).

5. Marusyn O.V. Halytskyi likarskyi visnyk. 2012; 19 (2) : 60-62 (in Ukrainian).

6. Bazylevych A. Ya., Barna O.M. Liky Ukrainy. 2014 ; 9 : 45-50 (in Ukrainian).

7. Prikhodko V.Yu., Kononenko E.A., Moreva D.Yu., Kashkovskii D.O., Voloshchuk T.R. Liky Ukrany. 2014; 9 : 15-21 (in Russian).

8. Sohuiko Yu.R. Ukrainskyi morfolohichnyi almanakh. 2014 ; 10(2) : 137-140 (in Ukrainian).

9. Doklinichni doslidzhennia likarskykh zasobiv : metodychni rekomendatsii [Preclinical Studies : Methodical

Recommendations]. Kyiv : Avitsenna; 2001 : 528 p. (in Ukrainian).

10. Mesova A.M., Isakhanova B.A., Espenbetova M.Zh., Zhetpisbaev B.A. Pat. № (19) KZ (13)AU(11) MPK A61K 31/573 Sposob vosproizvedeniia sakharnogo diabeta 2 tipa u molodykh krys [Method for the Replication of the II Type Diabetes Mellitus in Young Rats]. № 22018; opubl. 15.02.2009 ; Biul. № 12 (in Russian).

Надійшла до редакції 14.02.2016 